\title{
Growth-related changes in testicular mass and plasma testosterone concentrations in long-finned pilot whales, Globicephala melas
}

\author{
G. Desportes ${ }^{1 *}$, M. Saboureau ${ }^{2 \dagger}$ and A. Lacroix ${ }^{2}$ \\ ${ }^{1}$ Museum of Natural History, Fr-100 Tórshavn, Faroe Islands; and ${ }^{2}$ Centre d'Etudes Biologiques de Chizé, \\ CNRS, F-79360 Beauvoir sur Niort, France
}

\begin{abstract}
Blood samples and testes were collected from long-finned pilot whales (Globicephala melas) off the Faroe Islands at irregular intervals over a period of 3 years (July 1986-December 1989). Changes in testis mass $(n=674)$ and plasma testosterone concentrations $(n=214)$, measured by radioimmunoassay, were examined with respect to age, bodylength and bodymass of the animals. Corresponding to a rapid testicular growth (from $0.25 \mathrm{~kg}$ up to $1.9 \mathrm{~kg}$ ), puberty occurred in male pilot whales of $4.6-5.7 \mathrm{~m}$ in bodylength, 1.2-1.9 tonnes in bodymass and 11-22 years of age. Changes in plasma testosterone concentrations confirmed this result, with very low values $\left(<2 \mathrm{ng} \mathrm{ml}^{-1}\right)$ in immature animals (testis mass $<0.2 \mathrm{~kg}$ ), followed by a sharp increase (from 2 to $29 \mathrm{ng} \mathrm{ml}^{-1}$ ) during the pubertal period, and the maintenance of high concentrations with large variability ( $>1.5 \mathrm{ng} \mathrm{ml}^{-1}$ to $14 \mathrm{ng} \mathrm{ml} \mathrm{ml}^{-1}$ ) in mature males. Testosterone concentrations were significantly correlated with testis mass $(P<0.001)$, but not with bodylength or age, and very large individual variations were observed in mature males. The average age, length and mass at the attainment of sexual maturity were estimated at $16.99 \pm 0.30$ years, $5.162 \pm 0.013 \mathrm{~m}$ and $1.403 \pm 0.005$ tonnes, respectively.
\end{abstract}

\section{Introduction}

Little is known about sexual maturity and gonadal activity of males of many cetaceans, particularly offshore odontocetes. More information is needed for a better understanding of the reproductive strategy and behaviour of these long-living mammals (e.g. up to 46 and 59 years for male and female long-finned pilot whales, respectively; Bloch et al., 1993). Most of the observations made on cetacean male reproduction are based on morphological or gross histological observations and measurements of the masses of sexual organs from species taken in fisheries or stranded animals (Hohn et al., 1985; van Bree et al., 1986; Martin et al., 1987; Collet and Robineau, 1988; Lockyer et al., 1988; and for reviews, see Collet, 1981; Perrin et al., 1984; Bryden and Harrison, 1986; Evans, 1987). The determination of the concentrations of sexual hormones to characterize and specify the reproductive function was developed in cetaceans only during the last decade, because of difficulties in sampling. However, most studies deal mainly with captive females of one species, the bottlenose dolphin, and are oriented towards ovulation and pregnancy diagnosis and artificial insemination (Richkind, 1977; Sawyer-Steffan and Kirby, 1980; Sawyer-Steffan et al., 1983; Kirby, 1984, 1990; Kirby and Ridgway, 1984; Schroeder, 1984; Wells, 1984; Ólafsson and Kjeld, 1986; Yoshioka et al., 1986; Kjeld and

\footnotetext{
*Present address: Stejlestræde 9, Bregnør, DK-5300 Kerteminde, Denmark †Present address: Laboratoire de Neurobiologie des Fonctions Rythmiques et Saisonnières, URA-CNRS 1332, Université L. Pasteur, 12 rue de l'Université, F-67000 Strasbourg, France.

Revised manuscript received 18 May 1994
}

Amason, 1989; Ozharovskaya, 1990; Schroeder and Keller, 1990; Yoshioka, 1991; Yoshioka et al., 1991; Kjeld, 1992). Data on circulating testosterone concentrations are scarce and are mainly for bottlenose dolphins kept in captivity (Harrison and Ridgway, 1971; Judd and Ridgway, 1977; Wells, 1984; Schroeder and Keller, 1989; Kirby, 1990; Iemezh, 1991) and for fin and minke whales taken in fisheries (Ólafsson and Kjeld, 1986; Kjeld and Arnason, 1989; Kjeld, 1992; Yoshioka and Fujise, 1993).

In long-finned pilot whales (Globicephala melas), a species largely distributed in the North Atlantic Ocean, no gonadal hormonal assay has been reported. In previous attempts to determine sexual maturity in males, results were based on small sample sizes and varied according to authors, criteria and methods of age determination used (Sergeant, 1962; Desportes, 1982; Martin et al., 1987; Bloch, 1992). A unique opportunity to re-examine the reproductive function of male long-finned pilot whales more closely was offered within the framework of a large-scale international programme on the ecology and status of the species (Desportes, 1990; Desportes et al., 1992). Pilot whales are harvested off the Faroe Islands for subsistence purposes in a direct, uncommercial and opportunistic hunt (Bloch $e$ al., 1990; Sanderson, 1991). This catch was the focus of an intensive scientific sampling for 3 years.

Determination of the concentrations of hormones was performed in addition to the analysis of parameters previously considered. After adaptation and validation of the testosterone assay to this species, changes in testis mass and hormone concentrations were related to characterize the main gonadal status from birth to adulthood. 
Table 1. Plasma concentrations (means \pm SEM) of testosterone and $5 \alpha$-dihydrotestosterone ( $5 \alpha$-DHT) in long-finned pilot whales

\begin{tabular}{lcccc}
\hline Stage of maturity & $(n)$ & Testosterone $\left(\mathrm{ng} \mathrm{ml}^{-1}\right)$ & $5 \alpha$-DHT $\left(\mathrm{ng} \mathrm{ml}^{-1}\right)$ & Testosterone : DHT (ng ml ${ }^{-1}$ ) \\
\hline Immature & 6 & $1.24 \pm 0.23$ & $0.14 \pm 0.01$ & 8.9 \\
Maturing and mature & 5 & $0.62 \pm 0.11$ & $0.03 \pm 0.01$ & 20.7 \\
& 6 & $4.43 \pm 0.99$ & $0.45 \pm 0.10$ & 9.8 \\
& 7 & $12.89 \pm 1.28$ & $1.46 \pm 0.20$ & 10.1 \\
\hline
\end{tabular}

Results for maturing and mature specimens are presented according to testosterone concentrations: high, medium, and low.

\section{Materials and Methods}

\section{Animals}

During a period of 3 years (July 1986-December 1989) schools of pilot whales were caught at irregular intervals by the Faroese drive fishery. Forty schools were studied to obtain data on male reproductive status, bodylength, bodymass and age. Testis mass and blood samples were obtained from 674 and 214 specimens, respectively. For logistical reasons, complete data and sample sets were not obtained from all the whales. Exact sample sizes for each set of analyses are given in figure legends and tables.

The age determination, performed by $\mathrm{D}$. Bloch (Zoological Department, Museum of Natural History, FR-100 Tórshavn, Faroe Islands), was carried out by counting groups of growth layers in both dentine and cement on thin sections of decalcified teeth (Kasuya and Matsui, 1984; Bloch et al., 1993).

Blood samples were taken immediately after the animal was killed. They were collected from the neck vessels in $50 \mathrm{ml}$ heparinized tubes and kept on ice until processed in the laboratory. Plasma was divided into aliquots and stored at $-25^{\circ} \mathrm{C}$ until assays were performed. The duration of the drive (from the sighting place to the authorized whaling bay) and the time taken to slaughter the entire school varied; during the sampling period considered, they averaged 142 and $28 \mathrm{~min}$, respectively (Bloch et al., 1990). The state of stress undergone by each individual whale thus varied between and within schools, but was impossible to assess.

Testes were collected a few hours after the death of the animal, when the whales had been moved from the beach to the nearest quay. Desportes (1994) found that the asymmetry in mass and tissue maturation within a testis and within a pair of testes was sufficiently small to allow a single testis and a single histological sample to be used for routine assessment of sexual maturity in long-finned pilot whales. Thus, a single testis from whichever side was the most accessible for sampling was collected, and a single histological sample was taken from the mid-length cross-section of the testis taken from the side opposite to the epididymis. Testes were weighed fresh, without epididymis, to the nearest gram. Histological samples were fixed and preserved in $10 \%$ buffered formalin.

\section{Identification of sexual maturity}

Sexual maturity was identified by examining testicular tissue histologically. Samples for histology were processed using standard techniques, and slides were stained with haematoxylin-eosin. The maturity of testicular tissue was assessed by observing an entire section of about $1 \mathrm{~cm}^{2}$ and following criteria used for other mammals (see for example Courot et al., 1970). Three stages of histological maturity were used to characterize the maturity of testicular tissue, according to the proportion of mature seminiferous tubules: (1) immature ( $100 \%$ of the tubules were immature); (2) maturing ( $<100 \%$ of the tubules were mature); and (3) mature ( $100 \%$ of the tubules were mature).

\section{Testosterone assay}

Plasma testosterone concentrations were measured in duplicate by radioimmunoassay after steroid extraction with diethyl ether. The average recovery rate of labelled testosterone was $90.4 \% \pm 0.3 \%$. The accuracy was determined by adding different amounts of testosterone to the same plasma pool and by assaying different volumes of the same plasma. The sensitivity, determined as the smallest detectable quantity of hormone, was $<10 \mathrm{pg}$ per tube, which allows detection of plasma concentrations of about $0.03 \mathrm{ng} \mathrm{ml}^{-1}$. Intra-assay and interassay coefficients of variation were $6 \%$ and $13 \%$, respectively.

In this assay $5 \alpha$-dihydrotestosterone (DHT) gives the only significant crossreaction $(45 \%)$ with the testosterone antiserum used. In adult mammals the testosterone:DHT ratio usually ranges between 5 and 20, and the total testosterone-DHT complex is accepted as representing the testosterone concentration (for review, see Maurel, 1981). To check whether the same assimilation was acceptable for pilot whales, specific assays were performed for testosterone and DHT on 24 plasma samples from immature, maturing and mature animals. After steroid extraction with diethyl ether, DHT and testosterone were separated by chromatography on chromatolithe-A columns, and two specific radioimmunoassays were performed. The recovery rate of the labelled DHT was $60-80 \%$. The volume of plasma extracted had no influence on DHT concentration. The sensitivity was $10-15 \mathrm{pg}$ of DHT per tube. The variations in DHT and testosterone concentrations are presented in Table 1 . The testosterone:DHT ratio was low and practically constant $(<21)$ in adults and immature animals and was within the range for terrestrial mammals. Taking into account the low concentration of DHT and the crossreactivity of $45 \%$ with the antiserum used, we therefore considered the direct assay of testosterone without chromatography (i.e. total testosterone concentration plus $45 \%$ of the DHT 
Table 2. Ranges of testicular masses and plasma testosterone concentrations observed in long-finned pilot whales caught from March to September and from October to February according to reproductive stage

\begin{tabular}{|c|c|c|c|}
\hline Parameter & Stage of maturity & March-September & October-February \\
\hline \multicolumn{4}{|c|}{ Testis mass $(\mathrm{kg})$} \\
\hline & Immature & $0.010-0.346(197, P<0.001)$ & $0.009-0.340(168, P<0.001)$ \\
\hline & Maturing & $0.248-1.922 \quad(18, P<0.001)$ & $0.300-1.450 \quad(44, P<0.001)$ \\
\hline & Mature & $1.068-6.150 \quad(106)$ & $0.807-4.240(141)$ \\
\hline \multicolumn{4}{|c|}{ Testosterone (ng $\mathrm{ml}^{-1}$ ) } \\
\hline & Immature & $(58, P=0.183)$ & $(64, P<0.001)$ \\
\hline & Maturing & $(5, P=0.149)$ & $(16, P<0.001)$ \\
\hline & Mature & $1.87-22.07$ & $1.01-8.26$ \\
\hline
\end{tabular}

Sample sizes and probability of $t$ test values comparing means from one stage with the next are in parentheses.

concentration) as acceptable to be used routinely for pilot whale plasma samples.

\section{Estimation of age, length and mass at the attainment of sexual maturity}

Techniques used to estimate the average age at attainment of sexual maturity in cetaceans have been reviewed by Hohn (1989). The nonparametric method of the sum of the fraction of immature animals, as described by Hohn (1989), is used here to estimate the average age, length and mass at attainment of sexual maturity. These were calculated as the sum of the fraction of animals immature in each age or length or mass class between that of the youngest mature and that of the oldest immature animal, added to the age or length or mass of the first indeterminate age, length or mass class. The method was applied to the proportion of immature animals within an age class of I year, a length class of $5 \mathrm{~cm}$ (the sum of the fraction of immature animals and the variance was multiplied by five, i.e. the number of $\mathrm{cm}$ per length class), and a mass class of $100 \mathrm{~kg}$ (the sum of the fraction of immature animals and the variance was multiplied by 100 , i.e. the number of $\mathrm{kg}$ per mass class).

\section{Statistical analyses}

The results are expressed as means \pm SEM. Student's $t$ tests were performed for statistical comparisons, and Pearson's correlations were used (Sokal and Rohlf, 1981).

\section{Presentation of results}

Although this paper does not focus on the study of reproductive seasonality, which is dealt with elsewhere (Desportes et al., 1993), point data from mature males and a range of values are given according to the period of testicular activity to illustrate the variation due to seasonality (MarchSeptember and November-February).

\section{Results}

Testis growth

In Faroese pilot whales, the mass of a single testis at birth was about $0.009 \mathrm{~kg}$ and it was $6 \mathrm{~cm}$ long. In adults, the mass may reach $6.150 \mathrm{~kg}$ and the length $51 \mathrm{~cm}$. The epididymis mass was linearly correlated with testis mass $(n=275$, $P<0.001$ ). In immature animals, the testis mass increased very slowly and linearly with bodylength (rate $<1 \mathrm{~g} \mathrm{~cm}^{-1}$ of bodylength; Fig. Ia), bodymass (Fig. Ib) and age (Fig. Ic). A sharp upsurge in testis mass occurred roughly between 4.60 and $5.20 \mathrm{~m}$ in bodylength, 1 and 1.5 tonnes in bodymass and 11 and 18 years of age, the testis mass increasing at a rate of about $50 \mathrm{~g} \mathrm{~cm}^{-1}$ of bodylength. After this period of sharp increase, and despite large individual variations, testis mass continued to increase with bodylength $(n=236, P<0.001)$ and bodymass $(n=45, P<0.001)$ but it was no longer correlated with age after 21 years $(n=275, P=0.07)$. These different profiles suggest that fully grown males of large body size tend to have heavier testes than do smaller males, and that testis mass depends more on bodymass than on body length. Seasonality explained part of the individual variation observed in mature animals (Fig. 1; Table 2).

The rapid increase in growth rate of the testis corresponded to the time of maturation. Male pilot whales smaller than $4.55 \mathrm{~m}$, weighing less than 1.2 tonnes and younger than 11 years of age were immature. Testes weighing less than $0.248 \mathrm{~kg}$ were all histologically immature and testes heavier than $1.922 \mathrm{~kg}$ were all histologically mature. The maturing period appeared protracted from the overall data, taking place in testes weighing between $0.250 \mathrm{~kg}$ and $2 \mathrm{~kg}$.

The average age, length and mass of whales at the beginning of testis maturation were estimated to be $13.82 \pm 0.22$ years, $4.859 \pm 0.012 \mathrm{~m}$ and $1.214 \pm 0.003$ tonnes, respectively. Full histological maturity was attained on average at $16.99 \pm 0.30$ years, $5.162 \pm 0.013 \mathrm{~m}$ and $1.403 \pm 0.005$ tonnes.

\section{Plasma testosterone concentrations}

Testosterone concentrations in Faroese pilot whales ranged from 0.01 to $29.4 \mathrm{ng} \mathrm{ml}^{-1}$. The relationship between 

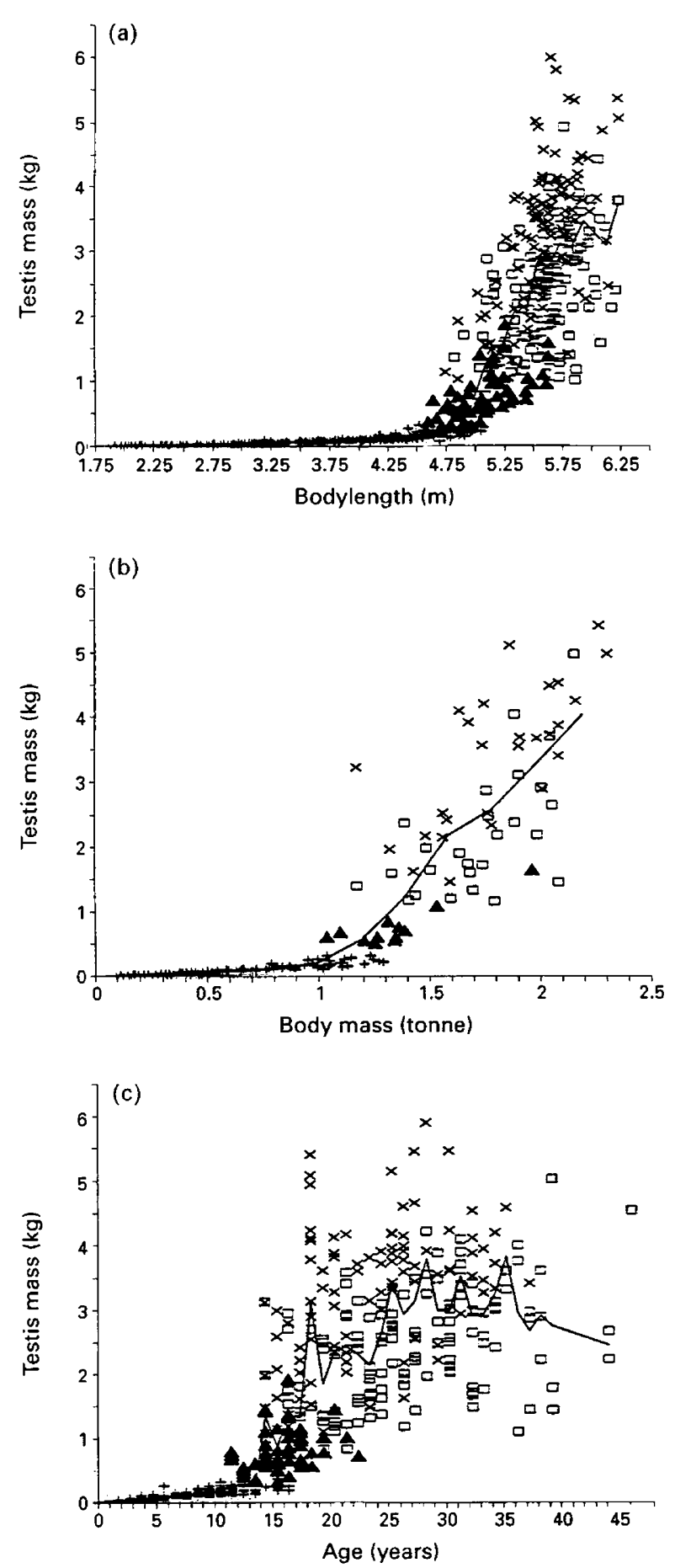

Fig. 1. Changes in testis mass in relation to (a) bodylength $(n=669)$, (b) body mass $(n=178)$ and (c) age $(n=602)$ in long-finned pilot whales. $(+)$ Immature testis; ( $\triangle$ ) maturing testis; $(\square)$ mature testis from animals caught between October and February; $(x)$ mature testis from animals caught between March and September. The lines connect the arithmetic means of testis mass for (a) length classes $(10 \mathrm{~cm})$, (b) mass classes $(200 \mathrm{~kg})$ and $(\mathrm{c})$ age classes (I year).

testosterone concentration and testis mass is presented in Fig. 2. A high concentration of testosterone $\left(5 \mathrm{ng} \mathrm{ml}^{-1}\right)$ was observed in males in which a single testis weighed between

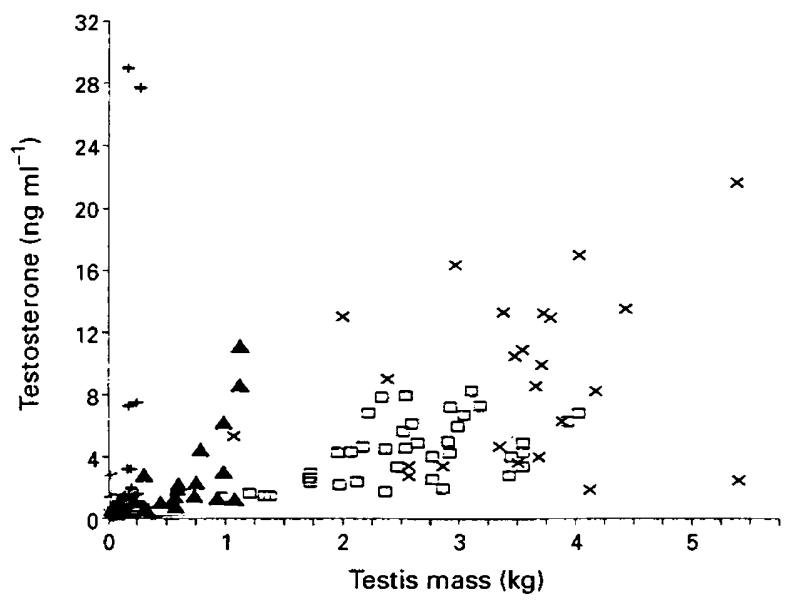

Fig. 2. Relationship between plasma testosterone concentration and testis mass $(n=156)$ in long-finned pilot whales. (+) Immature testis; (৫) maturing testis; ( $\square$ ) mature testis from animals caught between October and February; $(\times)$ mature testis from animals caught between March and September.

200 and $250 \mathrm{~g}$, about $\mathrm{I} \mathrm{kg}$ and $2 \mathrm{~kg}$ or more. In the group with a single testis mass of $>2 \mathrm{~kg}$, plasma testosterone concentrations were significantly correlated with testis mass $(P<0.001, n=54)$.

In animals younger than 8 years old, testosterone concentrations were undetectable or less than $\mathrm{Ing} \mathrm{ml}^{-1}$, except in a few calves. From 11 years of age and after the whales had reached $4.60 \mathrm{~m}$ in bodylength (i.e. simultaneously with the spurt in testis growth described above), plasma testosterone concentration began to increase. In animals 15 years old and older and longer than $5 \mathrm{~m}$, the testosterone concentration varied greatly and ranged from $1 \mathrm{ng} \mathrm{ml}^{-1}$ to $22 \mathrm{ng} \mathrm{ml}^{-1}$. The highest concentrations (i.e. $>10 \mathrm{ng} \mathrm{ml}^{-1}$ ) were observed between 15 and 32 years of age only and in animals caught between March and September. Part of the large variation observed in mature animals is explained by seasonality (Figs 2 and 3; Table 2).

Unexpectedly, comparatively high testosterone concentrations (Table 3) were observed in a few young immature individuals, or considered to be such on the basis of their age, bodylength and testis mass (although no testicular histology was performed in these instances).

\section{Discussion}

The present results correlated the lifelong testicular activity of long-finned pilot whales, determined by changes in testicular mass and plasma testosterone concentrations, with the evolution of morphological parameters such as bodylength, bodymass and age. The amount of data collected over a period of 3 years made it possible to obtain a representative sample for the characterization of each reproductive state from birth to adulthood in this long-living species of which males may reach at least 46 years. The pattern of testicular growth and histological examination of testicular tissue showed that puberty occurred between 11 and 22 years of age in males measuring between 4.6 and $5.7 \mathrm{~m}$ long and weighing between 

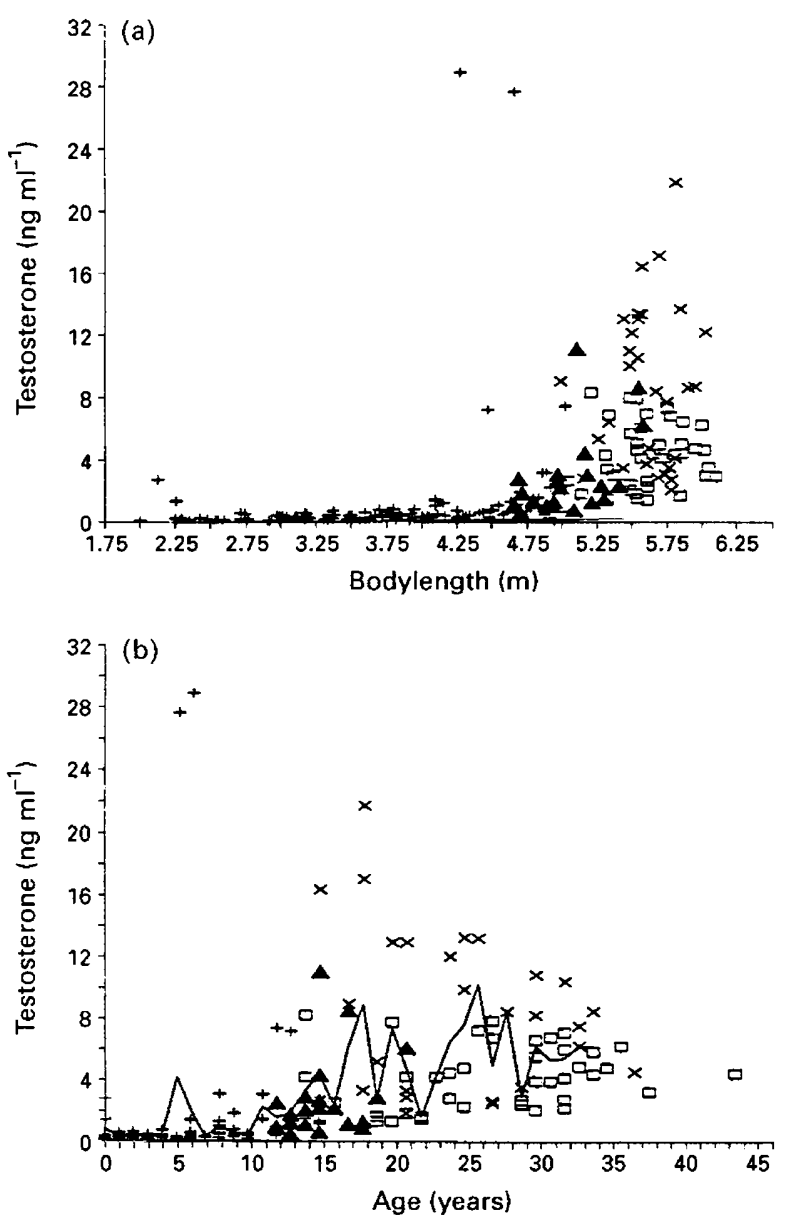

Fig. 3. Relationship between plasma testosterone concentration and (a) bodylength $(n=214)$ and (b) age $(n=194)$ in long-finned pilot whales. (+) Immature testis; $(\Delta)$ maturing testis; $(\square)$ mature testis from animals caught between October and February; $(\times)$ mature testis from animals caught between March and September.

1.2 and 1.9 tonnes. Maturing testes weighed between 0.250 and $1.922 \mathrm{~kg}$. Thus, the maturation period appeared to be protracted from the overall data. However, this apparent protracted duration of the pubertal stage is probably a sampling artifact and does not necessarily represent the individual rate of change. Indeed, if pilot whales progress through the pubertal stage at a rapid rate, but not in synchrony with their chronological peers as occurs in other species such as humans (Sinclair, 1973), then the overall data will underestimate the individual rate of change and overestimate the period over which the changes take place.

Previous data on testes obtained from 41 Faroese pilot whales caught during 1984 and 1985 (Bloch, 1992) gave a pattern of testis growth that fits well with the pattern presented in this study. The pattern of testis growth obtained from other locations in the North Atlantic for the same species is not inconsistent with our data, although the age at which the testicular growth spurt is said to occur is imprecise and somewhat variable because of very limited sample sizes and inadequate techniques of age determination. For example, the growth spurt took place when the animals had a bodylength of about $4.50 \mathrm{~m}$ and were $12-13$ years old in 90 males caught off Newfoundland (Sergeant, 1962), 4.25-5.00 $\mathrm{m}$ long and 9-14 years old in 11 males stranded on the British coast (Martin et al., 1987), and just under $5.00 \mathrm{~m}$ long in males 11 years old or older in 12 specimens stranded on the Icelandic coast (Sigurjónsson et al., 1993). Using the macroscopical detection of seminal fluid in the epididymis of 18 males as a criterion of sexual maturity, Sergeant (1962) found that the smallest mature male was $4.65 \mathrm{~m}$ long with a testis weighing just over $1.5 \mathrm{~kg}$ and that the largest immature animal was $5.1 \mathrm{~m}$ long with a testis also weighing just over $1.5 \mathrm{~kg}$. The smaller congeneric species, the shortfinned pilot whale, shows a similar pattern of testicular growth (Kasuya and Marsh, 1984). The testes stop growing at about 25 years of age, with larger males having heavier testes, and histological maturity (i.e. full maturity of testicular tissue observed on histological slides) is reached between 15 and 29 years of age.

In this study, the characterization of the reproductive status from birth to adulthood was also assessed for the first time in pilot whales by determining plasma testosterone concentrations by radioimmunoassay. The present results showed a wide range of testosterone concentrations in long-finned pilot whales with generally low concentrations in immature animals and large variations in mature males. A similar range of plasma testosterone concentrations was reported for bottlenose dolphins (Harrison and Ridgway, 1971), with low concentration in three immature males (from 0.07 to $3.9 \mathrm{ng} \mathrm{ml}^{-1}$ ) and a large variation in a mature male monitored over 2 years (from about 1.2 to $24.5 \mathrm{ng} \mathrm{ml}^{-1}$ ). Wells (1984) found a wider range in an adult male spinner dolphin monitored for 1 year, from $<\mathrm{Ing} \mathrm{ml}-1$ to $>60 \mathrm{ng} \mathrm{ml}^{-1}$, with a baseline range of $0-8 \mathrm{ng} \mathrm{ml}^{-1}$. Ranges reported for baleen whales also vary according to species: $0.03-7.0 \mathrm{ng} \mathrm{ml}^{-1}$ for mature fin whales; and $0.3-0.7 \mathrm{ng} \mathrm{ml}^{-1}$ for mature sei whales caught off Iceland in summer (J. Sigurjónsson and M. Kjeld, personal communication). Thus, ranges of testosterone concentrations vary between cetacean species, as in land mammal species (Gustafson and Shemesh, 1976). Consequently, the present results constitute a unique reference for Globicephala melas, but cannot be extended to another species without sufficient investigation.

From birth to the beginning of the pubertal period, testicular mass and plasma testosterone concentrations were usually low, although increasing slowly from birth onwards. However, in two very young suckling calves, probably $<3$ months old, high plasma testosterone concentrations were observed. These might possibly be compared to the transient neonatal increase occurring in different species (e.g. men: Forest et al., 1974; pigs: Meusy-Desolle, 1975; guinea-pigs: Pelardy and Delost, 1978). As in those species, this increase may be related to a first imprint of the nervous structures involved in postnatal sexual development (Harris, 1964).

The period of puberty was characterized by the testicular development and a parallel increase in plasma testosterone concentrations, attesting that maturational changes in spermatogenic as well as in steroidogenic components occurred simultaneously. The high concentrations of testosterone observed in a few calves approaching or at puberty are not unique; they may be compared with those reported during puberty in other mammals (McCann et al., 1974; Ghanadian 
Table 3. Plasma concentrations of testosterone with respect to age of long-finned pilot whales

\begin{tabular}{rccccc}
\hline Age (years) & Length $(\mathrm{m})$ & Testis mass $(\mathrm{kg})$ & Testis histology & Testosterone $\left(\mathrm{ng} \mathrm{ml}^{-\mathrm{I}}\right)$ & Month \\
\hline 0 & 2.24 & 0.014 & Immature & 1.4 & November \\
0 & 2.11 & 0.013 & Immature & 2.8 & November \\
8 & 4.89 & 0.184 & Immature & 3.1 & April \\
11 & 4.92 & 0.158 & Immature & 3.1 & April \\
13 & 4.49 & 0.160 & ND & 7.2 & April \\
12 & 5.06 & 0.232 & ND & 7.4 & April \\
5 & 4.70 & 0.248 & ND & 28.1 & September \\
6 & 4.30 & 0.140 & ND & 29.4 & September
\end{tabular}

ND: not determined.

et al., 1975; Berger et al., 1976; Bedair and Thibier, 1979; Saboureau and Dutourné, 1981). The high values of testosterone concentration and testis mass found in some young mature males have also been reported for males of other mammals at a similar stage (rat: Ghanadian et al., 1975; hedgehog: Saboureau and Dutourné, 1981). This increase in circulating steroid concentrations reflects changes in testicular sensitivity to gonadotrophins and the establishment of pituitary-testicular feedback.

In adult long-finned pilot whales, a wide range of testosterone concentrations was observed during life, the very low concentrations occurring only in immature animals. Such large individual variations are also reported in fin whales (Ólafsson and Kjeld, 1986; M. Kjeld and A. Arnason, personal communication), and may be due to several parameters. A seasonal factor widened the range of individual variations (see also Desportes et al., 1993), but the variations remained important among mature males caught from October to February. Part of the variation is probably the expression of diurnal patterns or pulses of testosterone, such as those described in many terrestrial species (bulls: Katongole et al., 1971; men: Naftolin et al., 1973; rats and mice: Bartke et al., 1973; rabbits: Rowe et al., 1973; badger: Maurel et al., 1981). Such diurnal and pulsatile variations are less apparent in longitudinal studies in which animals are bled several times a day or a month, and where results are presented as means. The variations observed may also be related to numerous factors such as nutritional state, exposure to receptive females, social status, muscular exercise and stress, which have been shown to influence reproduction (Perry and Rowlands, 1973; Bertram, 1975; Bronson, 1985; Frank, 1986), and particularly the pattern of testosterone secretion (McMillin et al., 1976). Stress, for example, might be of importance when animals are caught in a drive fishery. The last phase of the drive, the beaching and the killing are obviously stressful for the animals, but with a very variable state of stress undergone by individual males within the same pod and between pods. Social cues are also known to influence strongly the concentration of circulating testosterone in various land mammals (Faulkes and Abbott, 1991; Faulkes et al., 1991; van Jaarsveld and Skinner, 1991). This factor might be of importance in pilot whales since mating in this species appears to occur reciprocally between pods, with no evidence of strong reproductive dominance (Amos et al., 1991a, b, 1993).
In conclusion, the determination of plasma testosterone concentrations as well as testicular mass and testicular histology allowed the specification of the changes in reproductive activity in the long-finned pilot whales during their lifetime. The large individual variations and overlap between stages of maturity with the highest concentrations found in immature males approaching puberty, suggests that plasma testosterone concentrations cannot be used as a single indicator of sexual maturity in pilot whales. However, testosterone concentrations provide a suitable tool for following the sexual activity of male pilot whales over time. This is probably also the case for males of other cetacean species. The assessment of the reproductive status of individual males by measuring the concentration of testosterone present is widely used in land mammals, and is a particularly interesting tool in cetaceans because it is a harmless method that can be used in nonlethal investigations. As such, the study of sexual hormones in male cetaceans should be continued, with special emphasis on seasonal cycles and a longitudinal analysis of individual whales to understand individual rates of change better.

The authors thank the staff of the Faroese Natural History Museum and the Centre d'Etudes Biologiques de Chize for their invaluable participation in the field sampling and the laboratory processing, particularly R. Mouritsen, S. Skaaning, E. Stefansson, H. Gaasedal, $S$. Marillet and C. Trouvé. They also thank F. Jean-Caurant, J. A. Balbuena, L. Venturino and not least D. Bloch. They are indebted to A. Hohn and T. Kasuya for commenting and reviewing an earlier version of the manuscript. Two anonymous reviewers provided useful comments. Funding was given by the Faroese Government. The authors are especially grateful to K. Hoydal, Director of Fisheries, who made possible the International Research Programme on the Ecology and Status of Pilot Whales off the Faroe Islands.

\section{References}

Amos W, Barrett J and Dover GA (1991a) Breeding behaviour of pilot whales revealed by DNA fingerprinting Heredity 67 49-56

Amos W, Barrett J and Dover, GA (1991b) Breeding system and social structure in the Faroese pilot whale as revealed by DNA fingerprinting. Reports of the International Whaling Commission (Special Issue) 13 255-268

Amos W, Bloch D, Desportes G, Majerus TMO, Bancroft DR, Barrett JA and Dover GA (1993) A review of molecular evidence relating to social organisation and breeding system in the long-finned pilot whale Reports of the International Whaling Commission (Special Issue) 14 209-217 
Bartke A, Steele RE, Musto N and Caldwell B (1973) Fluctuations in plasma testosterone levels in adult male rats and mice Endocrinology 92 1223-1228

Bedair GAM and Thibier M (1979) Peripheral plasma androstenedione and testosterone concentrations in bulls before and during puberty Journal of Reproduction and Fertility 56 7-10

Berger M, Chazaud J, Jean-Faucher Ch, De Turckheim M, Veyssière G and Jean Cl (1976) Developmental patterns of plasma and testicular testosterone in rabbits from birth to 90 days of age Biology of Reproduction 15 561-564

Bertram BCR (1975) Social factors influencing reproduction in wild lions Joumal of Zoology, London 177 463-482

Bloch D (1992) Studies on the long-finned pilot whale in the Faroe Islands, 1976-86 Fródskaparrit 38-39 35-61

Bloch D, Desportes G, Hoydal K and Jean P (1990) Pilot whaling in the Faroe Islands. July 1986 - July 1988 North Atlantic Studies 2 36-44

Bloch D, Lockyer C and Zachariassen M (1993) Age and growth parameters of the long-finned pilot whales off the Faroe Islands Reports of the International Whaling Commission (Special Issue) 14 163-207

Bronson FH (1985) Mammalian reproduction: an ecological perspective Biology of Reproduction 32 1-26

Bryden MM and Harrison RJ (1986) Gonads and reproduction. In Research on Dolphins pp 149-159 Eds MM Bryden and RJ Harrison. Clarendon Press, Oxford

Collet A (1981) Biologie du Dauphin Commun Delphinus delphis $L$, en Atlantique Nord-Est. Thèse de Doctorat de 3ième cycle, Université de Poitiers

Collet A and Robineau D (1988) Data on the genital tract and reproduction in Commerson's dolphins, Cephalorhynchus commersonii (Lacépède, 1804), from the Kerguelen Islands Reports of the International Whaling Commission (Special Issue) 9 119-141

Courot M, Hochereau-de Reviers MT and Ortavant R (1970) Spermatogenesis. In The Testis pp 339-432 Eds AD Johnson, WR Gomes and NL Vandemark. Academic Press, New York, London

Desportes G (1982) Contribution à l'Etude de la Biologie de Globicephala melaena T. en Atlantique Nord-Est Diplôme d'Etudes Approfondies en Biologie et Physiologie Animale. Université de Poitiers

Desportes G (1990) Pilot whale research in the Faroe Islands. Presentation and preliminary results North Atlantic Studies 2 47-54

Desportes G (1994) Symmetry in testicular development in long-finned pilot whales Marine Mammal Science 10 376-380

Desportes G, Bloch D, Andersen LW and Mouritsen R (1992) The international research programme on the ecology and status of the long-finned pilot whale off the Faroe Islands Frodskaparrit 40 9-30

Desportes G, Saboureau M and Lacroix A (1993) Reproductive maturity and seasonality of male long-finned pilot whales, off the Faroe Islands Reports of the International Whaling Commission (Special Issue) 14 234-262

Evans PGH (1987) The Natural History of Whales and Dolphins. Christopher Helm, London

Faulkes CG and Abbott DH (1991) Social control of reproduction in breeding and non-breeding male naked mole-rats (Heterocephalus glaber) Joumal of Reproduction and Fertility 93 427-435

Faulkes CG, Abbott DH and Jarvis JUM (1991) Social suppression of reproduction in male naked mole-rats Heterocephalus glaber, Journal of Reproduction and Fertility $91593-604$

Forest MG, Sizonenko P, Cathiard AM and Bertrand J (1974) Hypophysogonadal function in humans during the first year of life. I. Evidence for testicular activity in early infancy Journal of Clinical Investigations 53 $819-828$

Frank LG (1986) Social organization of the spotted hyaena Crocuta crocuta. II Dominance and reproduction Animal Behavior 34 1510-1527

Ghanadian R, Lewis JG and Chisholm GD (1975) Serum testosterone and dihydrotestosterone changes with age in rats Steroids 25 753-762

Gustafson AW and Shemesh M (1976) Changes in plasma testosterone levels during the annual reproductive cycle of the hibernating bat, Myotis lucifugus lucifugus, with a survey of plasma testosterone levels in adult male vertebrates Biology of Reproduction 15 9-24

Harris GW (1964) Sex hormones, brain development and brain function Endocrinologie 75 627-648

Harrison RJ and Ridgway SH (1971) Gonadal activity in some bottlenose dolphins (Tursiops truncatus) Journal of Zoology, London 162 355-366

Hohn A (1989) Comparison of Methods to Estimate the Average Age at Sexual Maturation in Dolphins. Paper SC/41/O28 presented to the IWC Scientific Committee, San Diego, CA, May 1989
Hohn A, Chivers S and Barlow J (1985) Reproductive maturity and seasonality of male spotted dolphins, Stenella attenuata, in the Eastern Tropical Pacific Marine Mammal Science 1 273-293

lemezh AS (1991) Levels of plasmatic testosterone in mature and immature males of Black Sea bottlenose dolphin and Far East beluga Reports of the International Whaling Commission 41590 (résumé)

Judd HL and Ridgway SH (1977) Twenty-four hour patterns of circulating androgens and cortisol in male bottlenose dolphins. In Breeding Dolphins. Present Status, Suggestions for the Future pp 269-277 Eds SH Ridgway and K Benirschke. U.S. Marine Mammal Commission Report MMC-76/07, Washington, DC

Kasuya T and Marsh H (1984) Life history and reproductive biology of the short finned pilot whale, Globicephala macrorhynchus, off the Pacific coast of Japan Reports of the International Whaling Commission (Special Issue) 6 259-310

Kasuya T and Matsui S (1984) Age determination and growth of the shortfinned pilot whale off the pacific coast of Japan Scientific Reports of the Whales Research Institute 35 57-91

Katongole CB, Naftolin F and Short RF (1971) Relationship between blood levels of luteinizing hormone and testosterone in bulls, and the effect of sexual stimulation Journal of Endocrinology 50 457-466

Kirby VL (1984) Hormonal evaluation of ovulation and pregnancy in captive Tursiops truncatus Reports of the International Whaling Commission (Special Issue) 6479 (résumé)

Kirby VL (1990) Endocrinology of marine mammals. In Handbook of Marine Mammal Medicine: Health, Diseases, and Rehabilitation pp 303-351 Ed. LA Dierauf. CRC Press, Boston

Kirby VL and Ridgway SH (1984) Hormonal evidence of spontaneous ovulation in captive dolphins, Tursiops truncatus and Delphinus delphis Reports of the International Whaling Commission (Special Issue) 6 459-464

Kjeld M (1992) Sex hormones, puberty and relative pregnancy rate of fin whales off the coast of Iceland Reports of the International Whaling Commission 42770 (résumé)

Kjeld M and Arnason A (1989) Serum Progesterone and Testosterone Values in Fin Whales Caught off Iceland: a progress Report for 8 Years. Paper SC/4I/Ba 9 presented to the IWC Scientific Committee, San Diego, CA, June 1989

Lockyer C, Goodall RNP and Galeazzi AR (1988) Age and body-length characteristics of Cephalorhynchus commersonii from incidentally caught specimens off Tierra Del Fuego Reports of the International Whaling Commission (Special Issue) 9 103-118

McCann SM, Ojeda S and Negro-Vilar A (1974) Sex steroid, pituitary, and hypothalamic hormones during puberty in experimental animals. In Control of the Onset of Puberty pp 1-31 Eds MM Grumbach, GD Grave and FE Mayer. John Wiley \& Sons, New York

McMillin JM, Seal US, Rogers L and Erickson AW (1976) Annual testosterone rhythm in the black bear (Ursus americanus) Biology of Reproduction 15 163-167

Martin AR, Reynolds P and Richardson MG (1987) Aspects of the biology of pilot whales (Globicephala melaena) in recent mass strandings on the British coast Journal of Zoology 211 11-23

Maurel D (1981) Variations Saisonnières des Fonctions Testiculaire et Thyrö̈dienne en Relation avec l'Utilisation de l'Espace et du Temps chez le Blaireau Européen (Meles meles $L$.) et le Renard Roux (Vulpes vulpes L.) PhD Thesis, University of Montpellier II (Université des Sciences et Techniques du Languedoc)

Maurel D, Laurent A-M and Boissin J (1981) Short-term variations of plasma testosterone concentrations in the European badger (Meles meles) Journal of Reproduction and Fertility 61 53-58

Meusy-Desolle N (1975) Variations quantitatives de la testosterone plasmatique chez le porc male de la naissance à l'âge adulte Comptes rendus de L'Académie des Sciences, Paris 281 1875-1878

Naftolin F, Judd HL and Yen SSC (1973) Pulsatile patterns of gonadotropins and testosterone in man: the effect of clomiphene with and without testosterone Journal of Clinical Endocrinology and Metabolism 36 285-288

Ólafsson I and Kjeld M (1986) Serum progesterone and testosterone levels in fin whales (Balaenoptera physalus) Israelian Joumal of Veterinary Medicine $\mathbf{4 2}$ 300-306

Ozharovskaya LV (1990) The female reproductive cycle of Black Sea bottlenose dolphins as revealed by analysis of plasma progesterone levels Reports of the International Whaling Commission 40 481-485

Pelardy G and Delost P (1978) Secretion of the androgens in the male guinea-pig during the perinatal period Acta Endocrinologica 89 770-779

Perrin WF, Brownell RL and DeMaster DP (1984) Reproduction in whales, dolphins and porpoises Reports of the International Whaling Commission (Special Issue) 6 1-495 
Perry JS and Rowlands IW (Eds) (1973) The environment and reproduction in mammals and birds Joumal of Reproduction and Fertility Supplement 19

Richkind $M$ (1977) Steroid hormone studies in pregnant and nonpregnant bottlenose dolphins, Tursiops truncatus. Breeding Dolphins: Present Status, Suggestions for the Future pp 261-268 Eds SH Ridgway and K Benirschke. U.S. Marine Mammal Commission Report MMC-76/07, Washington, DC

Rowe PH, Shenton IC and Glover TD (1973) Testosterone levels in peripheral blood plasma of the rabbit under normal and experimental conditions Acta Endocrinologica (Kbh.) Supplement 177125

Saboureau M and Dutourné B (1981) The reproductive cycle in the male hedgehog (Erinaceus europaeus L.): a study of endocrine and exocrine testicular functions Reproduction, Nutrition and Development 21 109-126

Sanderson K (1991) Whales and Whaling in the Faroe Islands Department of Fisheries, Tórshavn, Faroe Islands

Sawyer-Steffan JE and Kirby VL (1980) A study of serum steroid hormone levels in captive female bottlenose dolphins, their correlation with reproductive status, and their application to ovulation induction in captivity. National Technical Information Service PB80-177199.

Sawyer-Steffan JE, Kirby VL and Gilmartin WG (1983) Progesterone and estrogens in the pregnant and nonpregnant dolphin, Tursiops truncatus, and the effects of induced ovulation Biology of Reproduction 28 897-901

Schroeder JP (1984) Induced reproductive-cycle events in Tursiops truncatus Reports of the International Whaling Commission (Special Issue) 6483 (résumé)

Schroeder P and Keller KV (1989) Seasonality of serum testosterone levels and sperm density in Tursiops truncatus Journal of Experimental Zoology $\mathbf{2 4 9}$ $316-321$

Schroeder P and Keller KV (1990) Artificial insemination of bottlenose dolphins. In The Bottlenose Dolphin pp 447-460 Eds S Leatherwood and RR Reeves. Academic Press, San Diego
Sergeant DE (1962) The biology of the pilot or pothead whale Globicephala melaena (Traill) in Newfoundland waters Bulletin of the Fisheries Research Board of Canada 132 1-84

Sigurjónsson J, Vikingsson G and Lockyer C (1993) Two mass strandings of pilot whales (Globicephala melas) on the coast of Iceland Reports of the International Whaling Commission (Special Issue) 14 407-423

Sinclair D (1973) Human Growth After Birth Oxford University Press, New York

Sokal RR and Rohlf FJ (1981) Biometry (2nd Edn). W.H. Freeman and Co., San Francisco

van Bree PJH, Collet A, Desportes G, Hussenot E and Raga JA (1986) Le dauphin de Fraser, Lagenodelphis hosei (Cetacea, Odontoceti), espèce nouvelle pour la faune d'Europe Mammalia 50 57-86

van Jaarsveld AS and Skinner JD (1991) Plasma androgens in spotted hyaenas (Crocuta crocuta): influence of social and reproductive development Journal of Reproduction and Fertility 91 195-201

Wells RS (1984) Reproductive behavior and hormonal correlates in Hawaiian spinner dolphins, Stenella longirostris Reports of the International Whaling Commission (Special Issue) 6 465-472

Yoshioka M (1991) Endocrinological studies on Cetacean Reproduction PhD Thesis, University of Tokyo

Yoshioka M and Fujise Y (1993) Serum testosterone and progesterone levels in Southem minke whales (Balaenoptera acutorostrata) Paper $\mathrm{SC} / 44 / \mathrm{SHB} 13$ presented to the IWC Scientific Committee, Tokyo, April 1993

Yoshioka M, Mohri E, Tobayama T, Aida K and Hanyu I (1986) Annual changes in serum reproductive hormone levels in captive female bottlenose dolphins Bulletin of the Japanese Society of Scientific Fisheries 52 1939-1946

Yoshioka M, Fujise Y, Kato H and Aida K (1991) Serum progesterone levels in Southern minke whales by reproductive status Reports of the International Whaling Commission 41583 (résumé) 